\title{
Stereoselective synthesis of (-)-pestalotin
}

\author{
A. Shashidhar Kumar, Pushpal Bhaket, and B. Venkateswara Rao* \\ Division of Organic Chemistry, Indian Institute of Chemical Technology \\ Hyderabad - 500 007, India \\ E-mail:venky@iict.res.in
}

Dedicated to Dr. A.V. Rama Rao on the occasion of his $70^{\text {th }}$ birthday

(received 16 Jul 04; accepted 05 Nov 04; published on the web 12 Nov 04)

\begin{abstract}
The asymmetric synthesis of (-)-pestalotin is described using $\mathrm{OsO}_{4}$-catalyzed asymmetric dihydroxylation and utilization of substituted aromatic system as a masked $\beta$-ketoester as the key steps in the reaction sequence.
\end{abstract}

Keywords: Asymmetric dihydroxylation, Birch reduction, ozonolysis

\section{Introduction}

Pestalotin 1, a gibberellin synergist, was first discovered by Kimura et al from a culture broth of Pestalotia Cryptomeriaecola Sawada, which is a fungus pathogenic for the Japanese cedar, Cryptomeria japonica. Later, Ellestad et $a^{2}$ also isolated $\mathbf{1}$ as a minor metabolite from the fermentation culture P880, an unidentified penicillium species and gave the code LLP-880 $\alpha$. The 6-substituted 5,6-dihydro-2-pyrone skeleton in pestalotin 1 which also occurs in many natural products show diverse biological activity ${ }^{3}$.

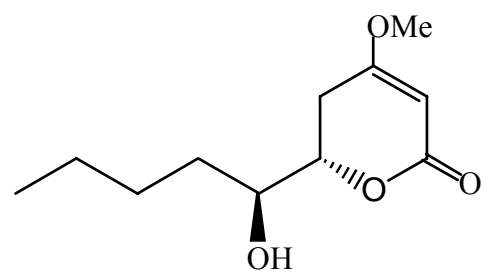

\section{(-)-Pestalotin 1}

The presence of two contiguous stereogenic centers in (-)-pestalotin $\mathbf{1}$ has made it an attractive synthetic target since its discovery. Several synthesis of racemic ${ }^{1 \mathrm{c}, 4 \mathrm{a}-\mathrm{c}}$ and optically active forms 
4d-p of pestalotin have been reported. In most of these syntheses the two chiral centers were built stepwise and also in some cases low stereoselectivity was observed.

In connection with our interest in utilizing substituted aromatic system as masked, 1,3-dione or 1,3-diol and 1,5-dione in the synthesis of natural products ${ }^{5}$, we report here a facile synthesis of $(-)$-pestalotin where the $m$-methoxy substituted benzene was utilized as a masked $\beta$-ketoester in turn to obtain the pyranone skeleton of compound 1. Also in our approach the asymmetric dihydroxylation (AD) developed by Sharpless was used to get the two chiral centers present in $\mathbf{1}$.

\section{Results and Discussion}

Our synthesis commenced with the $\mathrm{OsO}_{4}$ catalyzed asymmetric dihydroxylation (AD) ${ }^{6 \mathrm{a}, \mathrm{b}}$ of (E)Ethyl-2-heptenoate ${ }^{7} 2$ using 1,4-bis(dihydroquinin-9-O-yl)phthalazine [(DHQ) 2 -PHAL] as chiral ligand to afford the dihydroxyester 3 (scheme 1). It is well known that the straight chain $\alpha, \beta-$ unsaturated ester undergoes dihydroxylation with high enantioselectivity. ${ }^{8}$ Compound 3 when exposed to 2,2-dimethoxy propane in the presence of catalytic PTSA gave 4.

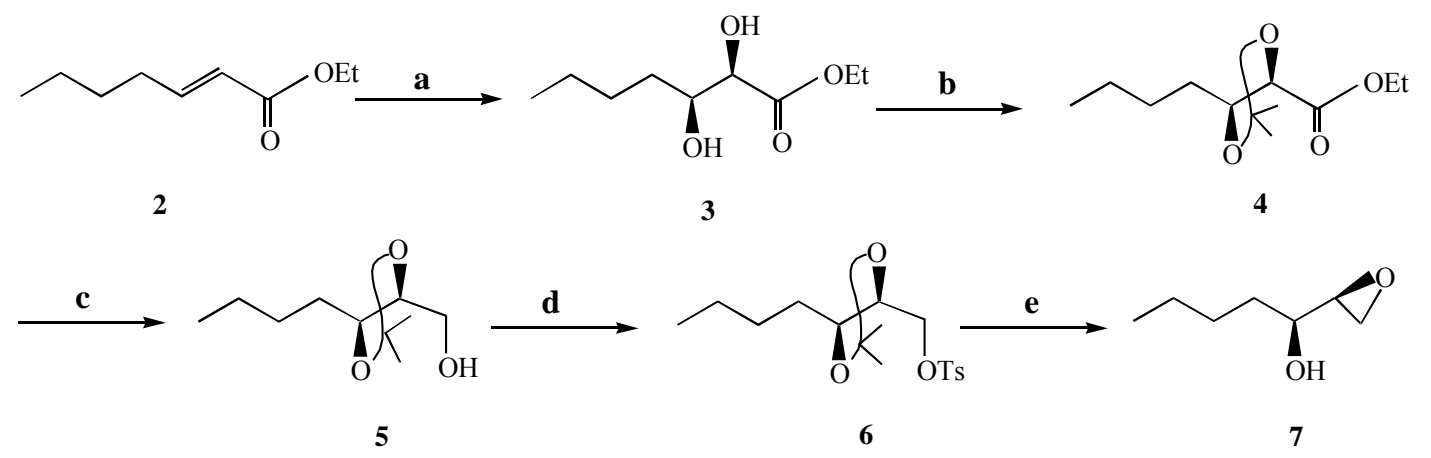

Scheme 1. Reagents and conditions: (a) $\mathrm{OsO}_{4}$. (DHQ) 2 - $\mathrm{PHAL}, \mathrm{K}_{3} \mathrm{FeCN}_{6}, \mathrm{~K}_{2} \mathrm{CO}_{3}, \mathrm{CH}_{3} \mathrm{SO}_{2} \mathrm{NH}_{2}$, t-BuOH/ $\mathrm{H}_{2} \mathrm{O}(1: 1), 16 \mathrm{~h}, 0^{\circ} \mathrm{C}, 71 \%, 97.35 \%$ ee; (b) 2,2 DMP, cat. $P-\mathrm{TsOH}, \mathrm{CH}_{2} \mathrm{Cl}_{2}, \mathrm{rt}, 16 \mathrm{~h}$, 98\%; (c) $\mathrm{LiCl}, \mathrm{NaBH}_{4}, \mathrm{EtOH}, \mathrm{THF}, 0^{\circ} \mathrm{C}$ to rt, $16 \mathrm{~h}, 76 \%$; (d) TsCl, $\mathrm{Et} 3 \mathrm{~N}$, cat. DMAP, $\mathrm{CH}_{2} \mathrm{Cl}_{2}$, $0^{\circ} \mathrm{C}$ to rt, 4 h, $85 \%$; (e) i. $P-\mathrm{TsOH}, \mathrm{MeOH}: \mathrm{H}_{2} \mathrm{O}(4: 1)$, rt, 20 h; ii. $\mathrm{K}_{2} \mathrm{CO}_{3}, \mathrm{MeOH} / \mathrm{H}_{2} \mathrm{O}(6: 1), 19 \mathrm{~h}$, rt, $68 \%$ (for two steps).

The ester 4 was smoothly reduced by $\mathrm{LiBH}_{4}{ }^{9}$, generated in situ, to afford the alcohol $\mathbf{5}$. The sulfonate ester $\mathbf{6}$ was readily prepared from $\mathbf{5}$ using $p$-toluene sulfonyl chloride, triethylamine and DMAP (catalytic). 

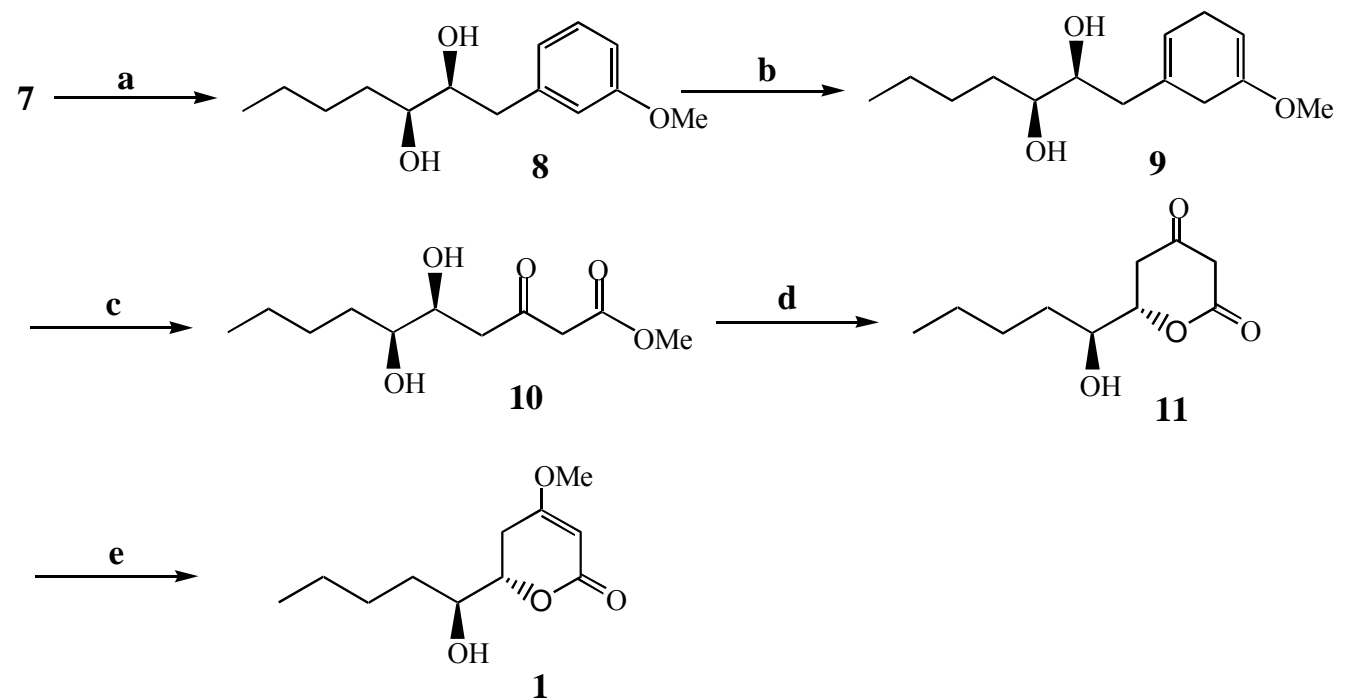

Scheme 2. Reagents and conditions: (a) $\mathrm{Mg}, \mathrm{m}$-bromo anisole, cat. $\mathrm{Cul}, \mathrm{THF},-20^{\circ} \mathrm{C}, 3.5 \mathrm{~h}$, $75.4 \%$; (b) Li (80 eq)/liq. $\mathrm{NH}_{3}$, THF, $-78^{\circ} \mathrm{C}$, EtOH, 1 h; (c) $\mathrm{O}_{3}, \mathrm{CH}_{2} \mathrm{Cl}_{2}$, Sudan-III, $-78^{\circ} \mathrm{C}, \mathrm{Me}_{2} \mathrm{~S}$, 30 min.; (d) $\mathrm{NaOH}$, THF, rt, $1.5 \mathrm{~h}, 10 \%$ (overall yield for three steps, 47\%, average yield for each step); (e) $\mathrm{Me}_{2} \mathrm{SO}_{4}, \mathrm{~K}_{2} \mathrm{CO}_{3}, \mathrm{CH}_{3} \mathrm{COCH}_{3}$, rt, 14 h, $60 \%$.

Deprotection of the isopropylidene moiety of $\mathbf{6}$ in acid medium followed by basification with $\mathrm{K}_{2} \mathrm{CO}_{3}$ in $\mathrm{MeOH} / \mathrm{H}_{2} \mathrm{O}$ afforded the epoxy alcohol 7, whose NMR spectral data $\left({ }^{1} \mathrm{H}\right.$ and $\left.{ }^{13} \mathrm{C}\right)$ was well in agreement with the reported data. ${ }^{10}$ When compound 7 was subjected to nucleophilic epoxide ring opening with $m$-methoxyphenyl magnesium bromide in the presence of catalytic $\mathrm{CuI}^{11}$, gave 8 (Scheme 2).

The crucial intermediate, $\beta$-keto ester $\mathbf{1 0}$ was unmasked from $\mathbf{8}$ via Birch reductionozonolysis sequence. ${ }^{5,12}$ Accordingly, when 8 was treated with Li/liq. $\mathrm{NH}_{3}$, EtOH the

dihydroanisole intermediate 9 was produced. Ozonolytic cleavage ${ }^{13,12 \mathrm{~d}}$ was performed on the unpurified Birch product to give the $\beta$-keto ester 10, which was carried to the next step without any purification. The $\delta$ - lactone 11 was obtained from 10 by treatment with $1 \mathrm{~N}$ aqueous $\mathrm{NaOH}$ solution which was subsequently methylated using dimethyl sulphate to furnish, the (-)-pestalotin $\mathbf{1}$ as a white solid after recrystallization [Hexane:Benzene $(1: 1)]$. The NMR $\left({ }^{1} \mathrm{H},{ }^{13} \mathrm{C}\right)$ spectral data of the synthetic sample were consonant with those of the reported product. ${ }^{1, c, 14}$

\section{Conclusions}

In summary, we have accomplished the synthesis of (-)-pestalotin using asymmetric dihydroxylation and Birch reduction-ozonolysis sequence of $m$-substituted anisyl ring as latent $\beta$ keto ester synthons for generating the 6-substituted 5,6-dihydro-2-pyrone unit. Use of $m$-Anisole 
unit as a masked form of $\beta$-ketoester has an advantage it can be introduced easily in to the skeleton and can be converted to $\beta$-keto ester at an appropriate stage in two step sequence.

\section{Experimental Section}

General Procedures. TLC was performed on Merck Kieselgel 60, $\mathrm{F}_{254}$ plates (layer thickness $0.25 \mathrm{~mm})$. Column Chromatography was performed on silica gel (60-120 mesh) using ethyl acetate and hexane mixture as eluent. Melting points were determined on a Fisher John's melting point apparatus and are uncorrected. IR spectra were recorded on Perkin-Elmer RX-1FT-IR system, In the case of syrups and liquids IR spectra was recorded by adding a drop of solution of compound in chloroform on $\mathrm{KBr}$ pellet. ${ }^{1} \mathrm{H}$ NMR $(200 \mathrm{MHz}),(400 \mathrm{MHz})$ and ${ }^{13} \mathrm{C} \mathrm{NMR}(50$ $\mathrm{MHz}$ ) spectra were recorded on Varian Gemini-200 $\mathrm{MHz}$ and Varian Unity $400 \mathrm{MHz}$ spectrometers. ${ }^{13} \mathrm{C}$ NMR (75 MHz and $125 \mathrm{MHz}$ ) spectra were recorded on Bruker Avance-300 $\mathrm{MHz}$ and DRX-500 MHz spectrometers. Optical rotations were measured with Jasco-Dip-360 digital polarimeter. The mass spectra were recorded on (VG MICROMASS-7070H) at $70 \mathrm{eV}$ using a direct inlet system. The LSIMS (FAB) spectra were recorded on VG AUTOSPEC instrument at the structure $(\mathrm{M}+\mathrm{H})$ at $\mathrm{m} / \mathrm{z}$. Elemental analyses were performed by Elementar analyser ; Vario EL( Model)(Germany).

Ethyl-2,3-dihydroxy-(2R, 3S)-heptanoate (3). To a solution of (DHQ) 2 -PHAL ligand (0.249 g, $0.32 \mathrm{mmol})$, potassiumferricyanide $(31.63 \mathrm{~g}, 96.14 \mathrm{mmol})$, potassium carbonate $(13.2 \mathrm{~g}, 96.15$ $\mathrm{mmol}), \mathrm{OsO}_{4}(0.325 \mathrm{~mL}, 0.2 \mathrm{~mol} \%)$ and methane sulfonamide $(3.04 \mathrm{~g}, 32.04 \mathrm{mmol})$ in a 1:1 mixture of t-BuOH: $\mathrm{H}_{2} \mathrm{O}(50: 50 \mathrm{~mL})$ was added (E)-ethyl-2-heptenoate 2 (5 g, $\left.32.05 \mathrm{mmol}\right)$ at $0^{0} \mathrm{C}$ and the mixture was stirred for $16 \mathrm{~h}$. The reaction was quenched by slow addition of sodium sulphite (20 g) and the suspension was warmed to room temperature, while stirring vigorously. After $45 \mathrm{~min}$, EtOAc $(40 \mathrm{~mL})$ was added and the aqueous layer was further extracted with EtOAc ( $60 \mathrm{~mL})$. The combined organic layers were washed with $2 \mathrm{~N}$ aq KOH solution $(56.11 \mathrm{~g}$ in $500 \mathrm{~mL}$ ), dried over anhydrous $\mathrm{Na}_{2} \mathrm{SO}_{4}$, and concentrated in vacuo. The residue was purified by silica gel chromatography eluting with EtOAc-hexane (1:4) to afford the pure product 3 (4.295 $\mathrm{g}, 71 \%)$ as a colourless liquid. $[\alpha]_{\mathrm{D}}{ }^{25}-9.21\left(c \mathrm{l}, \mathrm{CHCl}_{3}\right)$; IR $\left(\mathrm{KBr}, \mathrm{cm}^{-1}\right) 3413,2957$, 2867.5, 1737, 1464, 1375, 1209, 1137, 1090, 1029; 1 H NMR (200 MHz, $\left.\mathrm{CDCl}_{3}\right) \delta 0.92(3 \mathrm{H}, \mathrm{t}, J=$ $\left.7.0 \mathrm{~Hz}, \mathrm{CH}_{3}\left(\mathrm{CH}_{2}\right)_{3}-\right), 1.22-1.65\left(9 \mathrm{H}, \mathrm{m}, \mathrm{CH}_{3}\left(\mathrm{CH}_{2}\right)_{3}-\right.$ and $\left.-\mathrm{OCH}_{2} \mathrm{CH}_{3}\right), 1.85(1 \mathrm{H}, \mathrm{d}, J=8.0 \mathrm{~Hz}$, $\mathrm{OH}), 3.02(1 \mathrm{H}, \mathrm{d},-\mathrm{OH}, J=6.0 \mathrm{~Hz}), 3.72-3.88(1 \mathrm{H}, \mathrm{m},-\mathrm{CH}(\mathrm{OH})), 4.01(1 \mathrm{H}, \mathrm{dd}, J=2.0,6.0 \mathrm{~Hz}$, $-\mathrm{CH}(\mathrm{OH})), 4.26\left(2 \mathrm{H}, \mathrm{q}, J=7.0 \mathrm{~Hz},-\mathrm{OCH}_{2} \mathrm{CH}_{3}\right) ;{ }^{13} \mathrm{C} \mathrm{NMR}\left(75 \mathrm{MHz}, \mathrm{CDCl}_{3}\right) \delta 13.87,14.08$, 22.50, 27.82, 33.36, 61.92, 72.52, 73.14, 173.62; MS (FAB) $\mathrm{m} / \mathrm{z}: 191(\mathrm{M}+1)$. ; Anal. calcd for $\mathrm{C}_{9} \mathrm{H}_{18} \mathrm{O}_{4}$ : C, 56.82 ; H, 9.54. Found: C, 56.84; H, 9.58.

Ethyl 5-butyl-2,2-dimethyl-(4R, 5S)-1,3-dioxolane-4-carboxylate (4). To a solution of the diol $3(2.77 \mathrm{~g}, 14.57 \mathrm{mmol})$ in anhydrous $\mathrm{CH}_{2} \mathrm{Cl}_{2}(25 \mathrm{~mL})$ were added 2,2-dimethoxypropane $(2.3 \mathrm{~mL}$,

$18.95 \mathrm{mmol})$ and $p$ - $\mathrm{TsOH}(0.015 \mathrm{~g}, 0.078 \mathrm{mmol})$. The reaction was stirred for $16 \mathrm{~h}$ at room temperature. The reaction mixture was neutralised with $\mathrm{Et}_{3} \mathrm{~N}(2 \mathrm{~mL})$ and concentrated in vacuo. 
The residue was purified by silica gel chromatography eluting with EtOAc-hexane $(1: 19)$ to afford $4(3.27 \mathrm{~g}, 97.7 \%)$ as a coloured liquid. $[\alpha]_{\mathrm{D}}{ }^{25}-14.04\left(\mathrm{c} 1, \mathrm{CHCl}_{3}\right)$; IR $\left(\mathrm{KBr}, \mathrm{cm}^{-1}\right) 2988$, 2936, 2870, 2127, 1759, 1458, 1376, 1265, 1192, 1097; ${ }^{1} \mathrm{H}$ NMR $\left(200 \mathrm{MHz}, \mathrm{CDCl}_{3}\right) \delta 0.92(3 \mathrm{H}$, $\left.\mathrm{t}, J=6.5 \mathrm{~Hz}, \mathrm{CH}_{3}\left(\mathrm{CH}_{2}\right)_{3}-\right), 1.21-1.53\left(13 \mathrm{H}, \mathrm{m}, \mathrm{CH}_{3}\left(\mathrm{CH}_{2}\right)_{2},-\mathrm{OCH}_{2} \mathrm{CH}_{3}\right.$ and $\left.-\mathrm{C}\left(\mathrm{CH}_{3}\right)_{2}\right), 1.60-$ $1.80\left(2 \mathrm{H}, \mathrm{m},-\mathrm{CH}_{2}-\mathrm{CH}(\mathrm{O})\right), 4.00-4.10(2 \mathrm{H}, \mathrm{m},-\mathrm{CH}(\mathrm{O}-)-\mathrm{CH}(\mathrm{O}-)), 4.22(2 \mathrm{H}, \mathrm{q}, J=7.0 \mathrm{~Hz}$, $\left.\mathrm{OCH}_{2} \mathrm{CH}_{3}\right) .{ }^{13} \mathrm{C} \mathrm{NMR}\left(125 \mathrm{MHz}, \mathrm{CDCl}_{3}\right) \delta 13.59,13.92,22.34,25.54,27.01,27.52,33.07$, 60.90, 79.13, 110.52, 170.73. EIMS m/z: $215\left(\mathrm{M}^{+}{ }_{-} \mathrm{CH}_{3}\right)$, 157, 144, 127, 119, 93, 81, 65; Anal. calcd for $\mathrm{C}_{12} \mathrm{H}_{22} \mathrm{O}_{4}$ : C, $62.58 ; \mathrm{H}, 9.62$. Found: C, 62.73; H, 9.68.

5-Butyl-2,2-dimethyl -(4S, 5S)-1,3-dioxolan-4-ylmethanol (5). A ice cooled solution of anhydrous $\mathrm{LiCl}(1.50 \mathrm{~g}, 35.56 \mathrm{mmol})$ and $\mathrm{NaBH}_{4}(1.34 \mathrm{~g}, 35.5 \mathrm{mmol})$ in dry ethanol $(15 \mathrm{~mL})$ was stirred for $30 \mathrm{~min}$, to it ester $4(3.27 \mathrm{~g}, 14.23 \mathrm{mmol})$ dissolved in dry THF (15 mL) was added over $10 \mathrm{~min}$. The reaction mixture was brought to room temperature and stirred for $16 \mathrm{~h}$. The solid precipitate was filtered and washed with EtOAc $(3 \times 50 \mathrm{~mL})$ and EtOH $(10 \mathrm{~mL})$. The filtrate was concentrated in vacuo and the residue dissolved in EtOAc, treated with sat. $\mathrm{NH}_{4} \mathrm{Cl}$ $(50 \mathrm{~mL})$ at $0^{\circ} \mathrm{C}$ and extracted with EtOAc $(3 \times 50 \mathrm{~mL})$. Combined organic layers were extracted with $\mathrm{H}_{2} \mathrm{O}$ and sat. $\mathrm{NaCl}$, dried over $\mathrm{Na}_{2} \mathrm{SO}_{4}$, and concentrated in vacuo. The residue was purified by silica gel chromatography eluting with EtOAc-hexane (7:93) to furnish the alcohol 5 (2.02 g, $76 \%$ ) as a colourless oil. $[\alpha]_{\mathrm{D}}{ }^{25}-23.77\left(\mathrm{c} 1, \mathrm{CHCl}_{3}\right)$; IR $\left(\mathrm{KBr}, \mathrm{cm}^{-1}\right) 3460,2986,2933,2870$, 1460, 1375, 1219, 1168, 1104, 1048; 1 H NMR (200 MHz, CDCl $) \delta 0.94\left(3 \mathrm{H}, \mathrm{t}, J=7.0 \mathrm{~Hz}, \mathrm{CH}_{3}\right.$ $\left.\left(\mathrm{CH}_{2}\right)_{3}-\right)$, 1.26-1.65 (12H, m, $\mathrm{CH}_{3}\left(\mathrm{CH}_{2}\right)_{3}$ and $\left.-\mathrm{C}\left(\mathrm{CH}_{3}\right)_{2}\right), 1.92(1 \mathrm{H}$, br s, $-\mathrm{OH}), 3.52-3.92(4 \mathrm{H}, \mathrm{m}$, $\left.-\mathrm{CH}(\mathrm{O})-\mathrm{CH}(\mathrm{O}) \mathrm{CH}_{2} \mathrm{OH}\right) ;{ }^{13} \mathrm{C} \mathrm{NMR}\left(75 \mathrm{MHz}, \mathrm{CDCl}_{3}\right) \delta 13.85,22.71,27.03,27.36,28.06,32.79$, 62.19, 77.00, 81.58, 108.55; EIMS m/z: $173\left(\mathrm{M}^{+}-\mathrm{CH}_{3}\right), 157,95,81,69,59$; FAB-MS m/z:189( $\mathrm{M}+1)$.; Anal. calcd for $\mathrm{C}_{10} \mathrm{H}_{20} \mathrm{O}_{3}: \mathrm{C}, 63.80 ; \mathrm{H}, 10.71$. Found: $\mathrm{C}, 63.79 ; \mathrm{H}, 10.70$.

5-Butyl-2,2-dimethyl-4-(4-methylphenylsulfonyloxymethyl)-(4S, 5S)-1,3-dioxolane (6). To a stirred solution of compound $5(1.95 \mathrm{~g}, 10.39 \mathrm{mmol})$ in dry $\mathrm{CH}_{2} \mathrm{Cl}_{2}$, were added triethylamine (2.9 mL, $20.78 \mathrm{mmol})$, $p$-toluene sulfonylchloride $(2.17 \mathrm{~g}, 11.42 \mathrm{mmol})$ and DMAP (catalytic) at $0^{\circ} \mathrm{C}$. After stirring at room temperature for $4 \mathrm{~h}$, the reaction mixture was extracted with $\mathrm{H}_{2} \mathrm{O}$ and sat. $\mathrm{NaCl}$, dried over anhydrous $\mathrm{Na}_{2} \mathrm{SO}_{4}$, and concentrated in vacuo. The residue was purified by silica gel chromatography eluting with EtOAc-hexane (3:97) to afford 6 (3.02 g, 85\%) as a colourless oil. $[\alpha]_{\mathrm{D}}{ }^{25}-18.16\left(c 1, \mathrm{CHCl}_{3}\right)$; IR $\left(\mathrm{KBr}, \mathrm{cm}^{-1}\right) 3417,2941,2871,1744,1705,1598$, 1456, 1371, 1220, 1189, 1098, 983, 818, 771.

$1 \mathrm{H} \mathrm{NMR}\left(200 \mathrm{MHz}, \mathrm{CDCl}_{3}\right) \delta 0.91\left(3 \mathrm{H}, \mathrm{t}, J=7.5 \mathrm{~Hz}, \mathrm{CH}_{3}\left(\mathrm{CH}_{2}\right)_{3}-\right), 1.23-1.42\left(10 \mathrm{H}, \mathrm{m}, \mathrm{CH}_{3}\right.$ $\left(\mathrm{CH}_{2}\right)_{2} \mathrm{CH}_{2}$ and $\left.-\mathrm{C}\left(\mathrm{CH}_{3}\right)_{2}\right), 1.45-1.60\left(2 \mathrm{H}, \mathrm{m},-\mathrm{CH}_{2} \mathrm{CH}-(\mathrm{O})\right), 2.45\left(3 \mathrm{H}, \mathrm{s}, \mathrm{Ar}-\mathrm{CH}_{3}\right), 3.65-3.82$ $(2 \mathrm{H}, \mathrm{m},-\mathrm{CH}(\mathrm{O})-\mathrm{CH}(\mathrm{O})-), 4.05\left(2 \mathrm{H}, \mathrm{d}, J=5.0 \mathrm{~Hz},-\mathrm{CH}_{2}-\mathrm{OAr}\right), 7.35$ (2H, d, J = 8.5 Hz, Ar-), $7.80(2 \mathrm{H}, \mathrm{d}, J=8.5 \mathrm{~Hz}, \mathrm{Ar}-) ;{ }^{13} \mathrm{C} \mathrm{NMR}\left(75 \mathrm{MHz}, \mathrm{CDCl}_{3}\right) \delta 13.83,21.57,22.58,26.64,27.23$, 27.88, 32.69, 69.14, 77.75, 78.15, 109.23, 127.95, 129.81, 144.94; EIMS m/z: $327\left(\mathrm{M}^{+}{ }_{-} \mathrm{CH}_{3}\right)$, 213, 155, 95, 91; Anal. calcd for $\mathrm{C}_{17} \mathrm{H}_{26} \mathrm{O}_{5} \mathrm{~S}: \mathrm{C}, 59.62$; H, 7.65. Found: C, 59.31; H, 7.57.

1-[(2S)-Oxiran-2-yl]-(1S)-pentan-1-ol (7). To a solution of compound 6 (2.93 g, $8.56 \mathrm{mmol})$ in MeOH: $\mathrm{H}_{2} \mathrm{O}(25.0 \mathrm{~mL}, 4: 1)$ was added pTSA $(0.295 \mathrm{~g}, 1.55 \mathrm{mmol})$ and stirred at room temperature for $20 \mathrm{~h}$. The reaction mixture concentrated in vacuo and extracted with $\mathrm{CH}_{2} \mathrm{Cl}_{2}$ 
( $3 \times 20 \mathrm{~mL})$. The combined organic layers were washed with $\mathrm{H}_{2} \mathrm{O}$ then sat. $\mathrm{NaCl}(30 \mathrm{~mL})$, dried over anhydrous $\mathrm{Na}_{2} \mathrm{SO}_{4}$, and concentrated in vacuo, to give diol tosyl derivative $(2.05 \mathrm{~g})$ which was used for subsequent reaction without purification.

To a solution of the diol tosyl derivative $(2.05 \mathrm{~g}, 8.61 \mathrm{mmol})$ in $\mathrm{MeOH}(20 \mathrm{~mL}), \mathrm{K}_{2} \mathrm{CO}_{3}$ $(0.75 \mathrm{~g}, 5.42 \mathrm{mmol})$ was added to the reaction mixture till $\mathrm{pH} 9$ and stirred at room temperature for $19 \mathrm{~h}$. The methanol was removed on the rotavapor keeping the temperature of the water bath below $30^{\circ} \mathrm{C}$. The residue was taken in $\mathrm{CH}_{2} \mathrm{Cl}_{2}$, washed with $\mathrm{H}_{2} \mathrm{O}$ then sat. $\mathrm{NaCl}$, dried over anhydrous $\mathrm{Na}_{2} \mathrm{SO}_{4}$, and concentrated in vacuo. The residue was purified by silica gel chromatography eluting with EtOAc-hexane (5:95) to afford $7(0.75 \mathrm{~g}, 68 \%),[\alpha]_{\mathrm{D}}{ }^{25}+4.37$ (c 1 , $\left.\mathrm{CHCl}_{3}\right)\left\{\right.$ lit. $\left.^{4 \mathrm{j}}[\alpha]_{\mathrm{D}}{ }^{23}+5.01\left(c 1.39, \mathrm{CHCl}_{3}\right)\right\} ;{ }^{1} \mathrm{H} \mathrm{NMR}\left(400 \mathrm{MHz}, \mathrm{CDCl}_{3}\right) \delta 0.91(3 \mathrm{H}, \mathrm{t}, J=7.0$ $\left.\mathrm{Hz}, \mathrm{CH}_{3}-\right), 1.30-1.54\left(4 \mathrm{H}, \mathrm{m}, \mathrm{CH}_{3}\left(\mathrm{CH}_{2}\right)_{2}-\right)$, 1.55-1.63 (2H, m, $\left.-\mathrm{CH}_{2}-\mathrm{CH}(\mathrm{OH})-\right), 1.71(1 \mathrm{H}, \mathrm{d}, J=$ $7.0 \mathrm{~Hz},-\mathrm{OH}), 2.67\left(1 \mathrm{H}, \mathrm{m}, \mathrm{H}_{\mathrm{a}}\right), 2.76\left(1 \mathrm{H}, \mathrm{m}, \mathrm{H}_{\mathrm{b}}\right), 2.92\left(1 \mathrm{H}, \mathrm{m}, \mathrm{H}_{\mathrm{c}}\right), 3.40(1 \mathrm{H}, \mathrm{m},-\mathrm{CH}(\mathrm{OH})-) ;{ }^{13} \mathrm{C}$ NMR $\left(75 \mathrm{MHz}, \mathrm{CDCl}_{3}\right) \delta 13.91,22.66,27.45,34.19,45.10,55.31,71.66$; Anal. calcd for $\mathrm{C}_{7} \mathrm{H}_{14} \mathrm{O}_{2}$ : C, 64.58; H, 10.84. Found: C, 64.56; H, 10.83.

1-(3-Methoxyphenyl)-(2S, 3S)-heptane-2,3-diol (8). A dried two necked round bottom flask $(100 \mathrm{~mL})$ was charged with activated magnesium $(0.93 \mathrm{~g}, 38.42 \mathrm{mmol})$ in dry THF $(15 \mathrm{~mL})$ and 1,2-dibromoethane $(0.05 \mathrm{~mL})$ was added and stirred for $15 \mathrm{~min}$. To this reaction mixture, $\mathrm{m}$ bromoanisole $(1.43 \mathrm{~g}, 7.68 \mathrm{mmol})$ in anhydrous THF $(5 \mathrm{~mL})$ was added drop wise over a period of $10 \mathrm{~min}$ and stirred for $30 \mathrm{~min}$ at the same temperature. The reaction mixture was cooled to $20^{\circ} \mathrm{C}$, CuI (catalytic) and compound $7(0.5 \mathrm{~g}, 3.84 \mathrm{mmol})$ in dry THF $(5 \mathrm{~mL})$ was added. The reaction was allowed to stir for $3.5 \mathrm{~h}$ at room temperature. The reaction mixture was quenched with sat. $\mathrm{NH}_{4} \mathrm{Cl}(30 \mathrm{~mL})$ at $0^{\circ} \mathrm{C}$ and extracted with EtOAc $(3 \times 25 \mathrm{~mL})$. The combined organic solution was washed with $\mathrm{H}_{2} \mathrm{O}$ and sat. $\mathrm{NaCl}$, dried over anhydrous $\mathrm{Na}_{2} \mathrm{SO}_{4}$, and concentrated in vacuo. The residue was purified by silica gel chromatography eluting with EtOAc-hexane (1:9) to furnish $8(0.69 \mathrm{~g}, 75.4 \%)$ as a white solid. mp 50-52.4 ${ }^{\circ} \mathrm{C} ;[\alpha]_{\mathrm{D}}{ }^{25}-20.06 .\left(\mathrm{c} 1, \mathrm{CHCl}_{3}\right)$; IR $\left(\mathrm{KBr}, \mathrm{cm}^{-1}\right)$ 3251, 2936, 1587, 1486, 1266, 1156, 1042, 1002, 844, 693.1 H NMR (200 MHz, $\left.\mathrm{CDCl}_{3}\right) \delta 0.98\left(3 \mathrm{H}, \mathrm{t},-\mathrm{CH}_{3}, J=7.3 \mathrm{~Hz}\right), 1.22-1.62\left(6 \mathrm{H}, \mathrm{m}, \mathrm{CH}_{3}-\left(\mathrm{CH}_{2}\right)_{3}\right), 1.83,1.98(2 \mathrm{H}, 2 \mathrm{br} \mathrm{s}, 2$ $\mathrm{OH}), 2.7$ (1H, dd, $J=10,14.6 \mathrm{~Hz}, \mathrm{H}-1), 2.85$ (1H, dd, $J=4.4,14.6 \mathrm{~Hz}, \mathrm{H}-1$ '), 3.42 (1H, m, H-2), $3.62(1 \mathrm{H}, \mathrm{m}, \mathrm{H}-3), 3.81\left(3 \mathrm{H}, \mathrm{s}, \mathrm{OCH}_{3}\right), 6.70-6.84(3 \mathrm{H}, \mathrm{m}, \mathrm{Ar}-\mathrm{H}), 7.15-7.28(1 \mathrm{H}, \mathrm{m}, \mathrm{Ar}-\mathrm{H}) ;{ }^{13} \mathrm{C}$ NMR ( $\left.75 \mathrm{MHz}, \mathrm{CDCl}_{3}\right) \delta 13.96,22.70,27.82,33.44,40.35,55.16,73.60,74.89,111.90$, 115.16, 121.67, 129.60, 139.78, 159.86; MS m/z \% 238(M+), 151, 122, 121, 91; FAB-MS m/z: $261(\mathrm{M}+\mathrm{Na}), 239(\mathrm{M}+1), 238(\mathrm{M}+)$. ; Anal. calcd for $\mathrm{C}_{14} \mathrm{H}_{22} \mathrm{O}_{3}$ : C, 70.55 ; H, 9.30. Found: C, $70.51 ; \mathrm{H}, 9.38$.

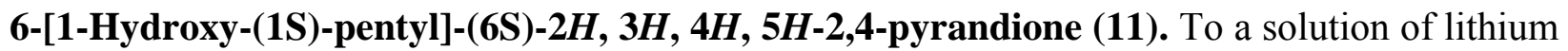
$(1.17 \mathrm{~g}, 168 \mathrm{mmol})$ in liq. ammonia $(100 \mathrm{~mL})$ at $-78^{\circ} \mathrm{C}$ (cooling was maintained by acetone/dry ice in the cold finger bath) was added compound $8(0.5 \mathrm{~g}, 2.1 \mathrm{mmol})$ dissolved in dry THF $(15 \mathrm{~mL})$. After the addition the acetone/dry ice bath was replaced by $\mathrm{CCl}_{4} /$ dry ice bath and stirred for $2 \mathrm{~h}$, again cooled to $-78^{\circ} \mathrm{C}$ and treated with dry EtOH $(6 \mathrm{~mL})$. The blue solution was stirred for $1 \mathrm{~h}$ and solid $\mathrm{NH}_{4} \mathrm{OAc}(5 \mathrm{~g})$ was added after which the reaction mixture was brought to room temperature. After all ammonia had evaporated the residue was partitioned between EtOAc/ 
$\mathrm{H}_{2} \mathrm{O}$. The aqueous layer was separated extracted with EtOAc $(2 \times 20 \mathrm{~mL})$ and the combined organic layers were washed with $\mathrm{H}_{2} \mathrm{O}$ then sat. $\mathrm{NaCl}$, dried over anhydrous $\mathrm{Na}_{2} \mathrm{SO}_{4}$, and concentrated in vacuo to afford $9(0.463 \mathrm{~g})$ as a colourless oil which was further carried for the next step without any purification.

To a solution of crude dihydroanisole $9(0.457 \mathrm{~g}, 1.904 \mathrm{mmol})$ in dry $\mathrm{CH}_{2} \mathrm{Cl}_{2}(15 \mathrm{~mL})$, were added $\mathrm{MeOH}(4 \mathrm{~mL})$, pyridine $(0.3 \mathrm{~mL})$ and a catalytic amount of sudan III. The pink solution was treated with a dilute stream of ozone in oxygen at $-78^{0} \mathrm{C}$ for $30 \mathrm{~min}$ untill it turned light yellow, at which point dimethylsulfide $(3 \mathrm{~mL})$ was added. The mixture was stirred at room temperature for $2 \mathrm{~h}$ after which the reaction was partitioned between EtOAc and $\mathrm{H}_{2} \mathrm{O}$. The organic layer was separated and the aqueous phase was extracted with EtOAc $(2 \times 15 \mathrm{~mL})$. The combined organic layers were dried over anhydrous $\mathrm{Na}_{2} \mathrm{SO}_{4}$, concentrated in vacuo to afford $\beta$ keto ester 10 (0.243 g,), which was used for subsequent reaction without purification.

To a solution of the $\beta$ - keto ester $10(0.243 \mathrm{~g}, 1.04 \mathrm{mmol})$ in dry THF $(8 \mathrm{~mL})$, was added aqueous $\mathrm{NaOH}(1 \mathrm{~N}, 6.4 \mathrm{~mL}, 6.4 \mathrm{mmol})$ and stirred at room temperature for $1.5 \mathrm{~h}$. To it aqueous $\mathrm{NH}_{4} \mathrm{Cl}$ was added and the $\mathrm{pH}$ was brought to $\sim 4$ by adding dilute $\mathrm{HCl}$. The reaction mixture was partitioned between EtOAc and $\mathrm{H}_{2} \mathrm{O}$. The organic layer was separated and the aqueous phase was extracted with EtOAc $(2 \times 20 \mathrm{~mL})$. The combined organic solution was washed with $\mathrm{H}_{2} \mathrm{O}$ then sat. $\mathrm{NaCl}$, dried over anhydrous $\mathrm{Na}_{2} \mathrm{SO}_{4}$, and concentrated in vacuo. Purification of the residue by silica gel chromatography eluting with EtOAc-hexane (2:3) gave $11(0.042 \mathrm{~g}, 10 \%$ overall yield for 3 steps, $47 \%$ average yield for each step) as a thick syrup. $[\alpha]_{\mathrm{D}}{ }^{25}-69.39$ (c 1.18 , $\mathrm{MeOH})$; IR (KBr,cm $\left.{ }^{-1}\right)$ 3390, 2932, 2868, 1723, 1667, 1409, 1278, 1226, 1137, 1059, 888, 832, 755; $1 \mathrm{H} \mathrm{NMR}\left(200 \mathrm{MHz}, \mathrm{CDCl}_{3}\right) \delta 0.95\left(3 \mathrm{H}, \mathrm{t},-\mathrm{CH}_{3}, J=7.8 \mathrm{~Hz}\right), 1.25-1.51\left(4 \mathrm{H}, \mathrm{m}, \mathrm{CH}_{3}\left(\mathrm{CH}_{2}\right)_{2}\right.$ $\left.-\mathrm{CH}_{2}\right), 1.51-1.75\left(2 \mathrm{H}, \mathrm{m}, \mathrm{CH}_{3}\left(\mathrm{CH}_{2}\right)_{2}-\mathrm{CH}_{2}\right), 2.23(1 \mathrm{H}$, br s, $-\mathrm{OH}), 2.66-2.76(2 \mathrm{H}, \mathrm{m}, \mathrm{H}-5), 3.47$ (2H, s, -CO-CH $\left.\mathrm{CH}_{2} \mathrm{CO}-\right), 3.65$ (1H, m, H-1'), 4.55 (1H, m, H-6); MS m/z \%: 156, 155, 141, 114, 101, 86.; Anal. calcd for $\mathrm{C}_{10} \mathrm{H}_{16} \mathrm{O}_{4}$ : C, 59.98 ; H, 8.05. Found: C, 59.97; H, 8.09.

6-[1-Hydroxy-(1S)-pentyl]-4-methoxy-(6S)-2H, 5H-2-pyranone (1). To a solution of $\delta$ lactone $11(0.042 \mathrm{~g}, 0.21 \mathrm{mmol})$ in anhydrous acetone $(10 \mathrm{~mL})$ were added dimethylsulfate in acetone $(0.55 \mathrm{M}, 0.4 \mathrm{~mL}, 0.209 \mathrm{mmol})$ and potassium carbonate $(0.043 \mathrm{~g}, 0.314 \mathrm{mmol})$. The resulting slurry was stirred at room temperature for $14 \mathrm{~h}$. Acetone was removed in the rotavapor and the residue was partitioned between EtOAc and $\mathrm{H}_{2} \mathrm{O}(20 \mathrm{~mL}, 3: 1)$. The organic layer was separated and the aqueous phase was extracted with EtOAc $(2 \times 15 \mathrm{~mL})$. The combined organic layers was washed with $\mathrm{H}_{2} \mathrm{O}$ then sat. $\mathrm{NaCl}$, dried over anhydrous $\mathrm{Na}_{2} \mathrm{SO}_{4}$, and concentrated in vacuo. The residue was purified by silica gel chromatography eluting with EtOAc-hexane $(3: 7)$ to afford 1. After recrystalisation in Hexane: Benzene $(2 \mathrm{~mL}, 1: 1)$ as a white solid $(0.027 \mathrm{~g}$, 60\%): m.p: $76-79^{\circ} \mathrm{C} ;[\alpha]_{\mathrm{D}}{ }^{25}-94.76$ (c 1, MeOH) $\left\{\right.$ lit. $^{2}[\alpha]_{\mathrm{D}}{ }^{25}-86.2$ (c 0.14, MeOH ) $\}$; IR (KBr, $\mathrm{cm}^{-1}$ ) 3434, 2950, 1705, 1619, $1236 .{ }^{1} \mathrm{H}$ NMR (400 MHz, $\left.\mathrm{CDCl}_{3}\right) \delta 0.96(3 \mathrm{H}, \mathrm{t}, J=7.4 \mathrm{~Hz}$, $\left.\mathrm{CH}_{3}\right), 1.28-1.68\left(6 \mathrm{H}, \mathrm{m}, \mathrm{CH}_{3}-\left(\mathrm{CH}_{2}\right)_{3}\right), 2.1(1 \mathrm{H}$, br s, OH), $2.24(1 \mathrm{H}, \mathrm{dd}, J=4,16.6 \mathrm{~Hz}, \mathrm{H}-5 \mathrm{a})$, $2.82(1 \mathrm{H}, \mathrm{dd}, J=12,16.6 \mathrm{~Hz}, \mathrm{H}-5 \mathrm{~b}), 3.60\left(1 \mathrm{H}, \mathrm{m}, \mathrm{H}-1\right.$ ') $, 3.79\left(3 \mathrm{H}, \mathrm{s}, \mathrm{OCH}_{3}\right), 4.28(1 \mathrm{H}, \mathrm{m}, \mathrm{H}-6)$, $5.14(1 \mathrm{H}, \mathrm{s}, \mathrm{H}-3):{ }^{13} \mathrm{C} \mathrm{NMR}\left(50 \mathrm{MHz}, \mathrm{CDCl}_{3}\right) \delta 13.90,22.54,27.57,29.54,32.33,56.09,72.37$, 
78.37, 89.96, 166.64, 173.10; FAB-MS m/z: 237(M+Na), 215(M+1), 197, 127, 109, 95, 81, 69, 55 ; Anal. calcd for $\mathrm{C}_{11} \mathrm{H}_{18} \mathrm{O}_{4}$ : C, 61.66 ; H, 8.46. Found: C, 61.65; H, 8.44.

\section{Acknowledgments}

ASK thanks CSIR, New Delhi for a research fellowship (S.R.F). One of the author (PB) thanks the UGC, New Delhi for financial assistance. We thank Dr. J. S. Yadav for his support and encouragement.

\section{References and Notes}

IICT Communication Number: 0407010

1. (a) Kimura, Y.; Katagiri, K.; Tamura, S. Tetrahedron Lett. 1971, 33, 3137. (b) Kimura, Y.; Katagiri, K.; Inoue, T.; Tamura, S. Agric. Biol. Chem. 1971, 35, 1313. (c) Kimura, Y.; Tamura, S. Agric. Biol. Chem. 1972, 36, 1925.

2. Ellestad, G. A.; McGahren, W. J.; Kunstmann, M. P. J. Org. Chem. 1972, 37, 2045.

3. Davies-Coleman, M. T.; Rivett, D. E. A. Progress in the Chemistry of Organic Natural Products, Herz, W.; Grisebach, H.; Kirby, G. W.; Tamm, Ch., Eds.; Springler-Verlag, 1989, Vol. 55, pp 1-35.

4. (a) Carlson, R. M.; Oyler, A. R. Tetrahedron Lett. 1974, 30, 2615. (b) Izawa, T.; Mukaiyama, T. Chem. Lett. 1978, 409. (c) Honda, T.; Okuyama, A.; Hayakawa, T.; Kondoh, H.; Tsubuki, M. Chem. Pharm. Bull. 1991, 39, 1866. (d) Meyer, H.; Seebach, D. Liebigs Ann Chem. 1975, 2261. (e) Seebach, D.; Meyer, H. Angew. Chem., Int. Ed. 1974, 13, 77. (f) Mori, K.; Oda, M.; Matsui, M. Tetrahedron Lett. 1976, 36, 3173. (g) Takeda, A.; Amano, E.; Tsuboi, S. Bull. Chem. Soc. Jpn. 1977, 50, 2191. (h) Kirihata, Y.; Ohta, K.; Yamamoto, S.; Ichimoto, I.; Ueda, H. Abstract of Papers, Annual Meeting of the Agricultural Chemical Society of Japan 1980, Fukuoka, p 211. (i) Midland, M. M.; Graham, R. S. J. Am. Chem. Soc. 1984, 106, 4294. (j) Mori, K.; Otsuka, T.; Oda, M. Tetrahedron 1984, 40, 2929. (k) Masaki, Y. ;Nagata, K.; Serizawa, Y.; Kaj, K. Tetrahedron Lett. 1984, 25, 95. (1) Hagiwara, H.; Kimura, K.; Uda, H. J. Chem. Soc., Chem. Commun. 1986, 860. (m) Zhang, J. C.; Curran, D. P. J. Chem. Soc., Perkin Trans I 1991, 2627. (n) Hagiwara, H.; Kimura, K.; Uda, H. J. Chem. Soc., Perkin Trans I 1992, 693. (o) Wang, Z.; Shen, M. Tetrahedron: Asymmetry 1997, 8, 3393. (p) Mayer, S. F.; Steinreiber, A.; Goriup, M.; Saf, R.; Faber, K. Tetrahedron: Asymmetry 2002, 13, 523.

5. (a) Rao, B.V.; Rao, A. S. Synth. Commun. 1995, 1531. (b) Shashidhar Kumar, A.; Haritha, B.; Rao, B. V. Tetrahedron Lett. 2003, 44, 4261. (c) Naveen Kumar, D.; Rao, B. V. Tetrahedron Lett. 2004, 10, 2227. 
6. (a) Kolb. H. C.; Van Nieuwenhze. M. S.; Sharpless. K. B. Chem. Rev. 1994, 94, 2483. (b) Sharpless. K. B.; Ambeng, W.; Benanni, Y. L.; Crispino, G. A.; Hartung, J.; Jeong, K. S.; Morikawa, H. L.; Wang, Z-M.; Xu, D.; Zhang, Z-I. J. Org .Chem. 1992, 57, 2768.

7. (E)-Ethyl-2-heptenoate (2) was prepared by the Wittig-olefination reaction of 1-pentanal and (carbethoxymethylidene)triphenylphosphorane. The trans-ester was isolated by silica gel chromatography eluting with AcOEt-hexane (1:99).

8. Enantiomeric purity of (3) were estimated to be $97.35 \%$ ee, by HPLC analysis of the corresponding dibenzoate (3a) $\left\{[\alpha]_{\mathrm{D}}{ }^{26.5}=-67.71\left(\mathrm{C} 1.03, \mathrm{CHCl}_{3}\right)\right.$ using a chiralcel OD (semi prep) column. (1\% i- propanol $/ \mathrm{n}$ - hexane, flow rate $2.0 \mathrm{~mL} / \mathrm{min}, \lambda=225 \mathrm{~nm}$, range: 0.05000AUFS).

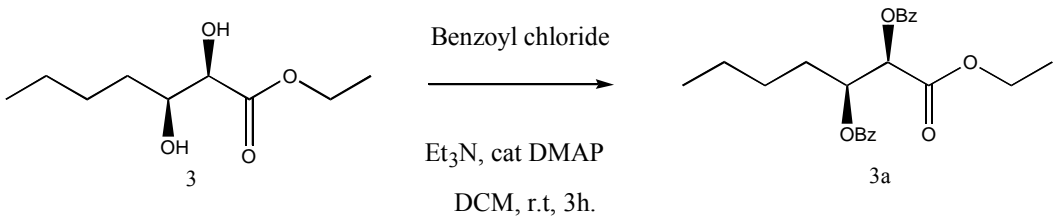

9. (a) Brown, H. C.; Choi, Y. M.; Narasimhan, S. Inorg. Chem. 1981, 20, 454. (b) Brown, H. C.; Narasimhan, S. J. Org. Chem. 1982, 47, 1604.

10. Mayer, S. F.; Steinreiber, A.; Orru, R. V. A.; Faber, K. Eur. J. Org .Chem. 2001, 4537.

11. Huynh, C.; Dergnini-Bonmechal, D.; Linstrumelle, G. Tetrahedron Lett. 1979, 1503.

12. (a) Birch, A. J.; Fitton, P.; Smith, D. C. C.; Steere, D. E.; Stelfox, A. R. J. Chem. Soc. 1963, 2209. (b) Kirkeno, C. L.; White, J. D. J. Org. Chem. 1985, 1316. (c) Bringmann, G.; Liebigs Ann. Chem. 1985, 2105. (d) Evans, D. A.; Gauchet-Prunet, J. A.; Carreira, E. M.; Charette, A. B. J. Org. Chem. 1991, 56, 741.

13. For the use of dyes in ozonolysis see: Veysoglu, T.; Mitscher, L. A.; Swayze, J. K. Synthesis $1980,807$.

14. Kimura, Y.; Suzuki, A.; Tamura, S. Agric. Biol. Chem. 1980, 44, 451. 